\title{
Effects of reduced and traditional tillage on soil properties and diversity of diatoms under winter wheat**
}

\author{
Jadwiga Stanek-Tarkowska ${ }^{*}$, Ewa A. Czyż ${ }^{1}$, Anthony R. Dexter ${ }^{2}$, and Cezary Stawiński \\ ${ }^{1}$ Rzeszów University, Department of Soil Science, Environmental Chemistry and Hydrology, Faculty of Biology and Agriculture, \\ Zelwerowicza 8 B, 35-601 Rzeszów, Poland \\ ${ }^{2}$ Institute of Soil Science and Plant Cultivation, State Research Institute, Department of Soil Science Erosion and Land Conservation, \\ Czartoryskich 8, 24-100 Puławy, Poland \\ ${ }^{3}$ Institute of Agrophysics, Polish Academy of Sciences, Doświadczalna 4, 20-290 Lublin, Poland
}

Received April 3, 2018; accepted May 7, 2018

\begin{abstract}
A b s t r a c t. The aim of this study was to quantify soil properties, microbial biodiversity and crop yield under two tillage systems used for winter wheat production in monoculture. The study was conducted in the period 2013-2016, on a long-term field experiment on a silt loam at the Krasne Research Station near Rzeszów, Poland. Traditional tillage involved soil inversion whereas reduced tillage was a non-inversion system. The following soil properties: chemical (soil organic carbon, $\mathrm{pH}$, available $\mathrm{P}, \mathrm{K}, \mathrm{Mg}$ ), physical (soil bulk density, water content, stability in water), and biological (the diversity of diatoms) were measured on samples collected throughout the growing season and at harvest. Soil organic carbon content, water content and bulk density in the $0-5$ and 5-10 cm layers were greater in reduced tillage than in traditional tillage. Under reduced tillage the amount of readily dispersible clay was reduced giving increased soil stability in water. Soil under reduced tillage had greater diversity of diatoms (139 taxa) than that under traditional tillage (102 taxa). Wheat yields were positively correlated with precipitation, soil water content and soil organic carbon, and negatively correlated with readily dispersible clay.

K e y w o r d s: soil stability in water, biodiversity, Triticum aestivum L., Bacillariophyceae, grain yield
\end{abstract}

\section{INTRODUCTION}

In Poland, winter wheat production traditionally uses plough tillage (TT) but there is growing interest in developing systems of reduced tillage (RT) which can also produce good conditions for plant growth (Czyż and Dexter, 2009).

*Corresponding author e-mail: jstanek@ur.edu.pl

**Financial support was received from the Programme of the Scientific Network No. 17/E-164/SN-019/2007, and also from Rzeszów University Research Programme WBR/KGCHŚiH/ DS./5/, 2013-2017.
Under RT, reduction of soil disturbance decreases mineralization of soil organic matter and can increase storage of soil organic carbon (SOC) Małecka et al. (2015). RT protects the sub-soil against compaction and erosion by water, can also increase the stability of the soil through increased SOC (Czyż and Dexter, 2009). RT has effects on soil physical properties: bulk density, water content (Fabrizzi et al., 2005; McVay et al., 2006; Mühlbachová et al., 2015 Pabin et al., 2003; Sławiński et al., 2012), soil stability (Czyż and Dexter, 2008, 2009); chemical: SOC (Gajda et al., 2017, 2018; Małecka et al., 2015; Mikanová et al., 2012), available forms of P, K and Mg (Franzluebbers, 2002; Małecka et al., 2015); and increased biological activity (Gajda et al., 2017) and diversity of diatoms (Stanek-Tarkowska and Noga 2012a,b; Stanek-Tarkowska et al., 2015) compared with TT. Czyż and Dexter (2009) reported that RT decreased the content of readily dispersible clay (RDC) and therefore increased soil stability. With RT, increased water content in the soil profile has been observed (Czyż and Dexter, 2009), and also an increase in bulk density in the top layers Gajda et al. (2017) in comparison with TT.

Crop growth and yield depend on the condition of the soil and the level of fertilization (NPK) and on climatic conditions (Arvidsson et al., 2013; Gajda et al., 2017; Małecka et al., 2015; Pisulewska et al., 2009). The grain yield of wheat grown in monoculture without soil inversion

(C) 2018 Institute of Agrophysics, Polish Academy of Sciences 
is usually reduced by $8-30 \%$, depending on the site, weather conditions and crop management. For example, in Poland Kordas (2009) found the average yield of winter wheat in 3 years of monoculture to be lower under RT by $14.5 \%$ and under no-tillage by $15.9 \%$ compared with TT. Impacts of crop cultivation systems, agrotechnical treatments on crop yields, plant uptake of macronutrients and biodiversity of the ecosystem have also been observed (Gajda et al., 2017, 2018; Kołodziejczyk et al., 2017; Mühlbachová et al., 2015).

The aim of this research was to compare the effects of traditional and reduced tillage on some soil properties: chemical (soil organic carbon, $\mathrm{pH}$, available $\mathrm{P}, \mathrm{K}, \mathrm{Mg}$ ), physical (soil bulk density, soil water content, readily dispersible clay), biological (the diversity of diatoms) and on the grain yield of winter wheat grown in monoculture.

\section{MATERIALS AND METHODS}

The research was carried out in 2013-2016 on a longterm field experiment started in 2008 at the Krasne Research Station near Rzeszów, Poland; latitude $50^{\circ} 03^{\prime} \mathrm{N}$; longitude $22^{\circ} 06^{\prime}$ E. The soil was a Haplic Luvisol formed on loess (IUSS Working Group WRB, 2006) with a silt loam texture

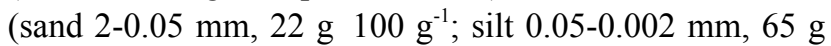

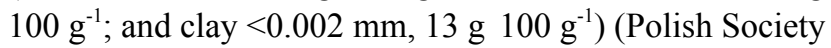
of Soil Science, PTG, 2008). The soil arable layer $(0-20 \mathrm{~cm})$ before the start of the experiment was characterized chemically, and had $5.3 \mathrm{pH}$ in $\mathrm{KCl}$, content of organic carbon

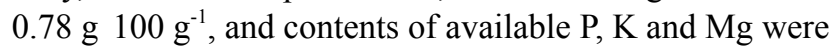
98,128 and $45 \mathrm{mg} \mathrm{kg}^{-1}$ soil, respectively.

Winter wheat cv. Bogatka was grown in monoculture under two different tillage systems: traditional (inversion) tillage (TT) and reduced (non-inversion) tillage (RT). TT was based on the mouldboard plough (to $25 \mathrm{~cm}$ depth). The straw after harvest was chopped and turned under. RT was based on a rigid-tine cultivator (to $10 \mathrm{~cm}$ depth) and soil crushing-loosening equipment, and straw was chopped and left on the surface. The experiment was set up on 1 ha plots arranged as a randomized block with 4 replications giving a total of 8 plots per year. Wheat was sown between 19 and 29 September, at a density of 400 seeds per $\mathrm{m}^{2}$ and at a sowing depth of 3-4 cm. Mineral fertilization was the same for both tillage systems and in each experimental year. An autumn-applied fertilizer (Polifoska) was applied at $18 \mathrm{~kg}$ $\mathrm{N} \mathrm{ha}^{-1}, 55 \mathrm{~kg} \mathrm{P} \mathrm{ha}^{-1}$ and $90 \mathrm{~kg} \mathrm{~K} \mathrm{ha}^{-1}$. Each spring, mineral fertilizer with nitrogen as ammonium nitrate was applied at $120 \mathrm{~kg} \mathrm{~N} \mathrm{ha}^{-1}$ in 3 doses: at beginning of spring growth: 60 $\mathrm{kg} \mathrm{ha}^{-1}$ (26-27 BBCH), at stem elongation: $30 \mathrm{~kg} \mathrm{ha}^{-1}$ (32-33 $\mathrm{BBCH})$ and at ear formation: $30 \mathrm{~kg} \mathrm{ha}^{-1}(55-56 \mathrm{BBCH})$. For weed control during the growing season, post-emergence, Chwastox Turbo $340 \mathrm{SL}$ was applied at $2.01 \mathrm{ha}^{-1}$. For disease control, the fungicide Juwell TT $483 \mathrm{SE}$ was applied at $1.21 \mathrm{ha}^{-1}$ at the stages of stalk shooting and ear formation.
Each year, soil samples for physical and chemical analysis were collected throughout the growing season, at ear formation $(55-56 \mathrm{BBCH}$, each year during the same season) and at harvest with 4 replications, from the six depths: $0-5,5-10,10-15,15-20,20-25$ and 30-35 cm depths. To determine the diversity of diatoms, soil samples were collected with 2 replications from the $0-5 \mathrm{~cm}$ layer and placed in three Petri dishes for measurement.

Winter wheat was harvested in one step using a plot combine 'SEEDMASTER' (Wintersteiger Seedmaster Universal Hydrostatic) in early August (on the following dates: 2.08.2013, 4.08.2014, 2.08.2015, 1.08.2016) from a $50 \mathrm{~m}^{2}$ area. Grain yields per 1 ha were calculated taking into account $15 \%$ moisture content.

Meteorological conditions and soil properties are presented in Tables 1 and 2. Temperature and precipitation data were from the Meteorological Station of Rzeszów University (Table 1). The years of the study 2013-2016 had higher mean air temperatures $\left(0.5,1.6,1.6,0.4^{\circ} \mathrm{C}\right.$, respectively) than the $8.4^{\circ} \mathrm{C}$ for the long-term average. The sums of precipitation were smaller by 56.6, 107.6, 279.8 and $197.3 \mathrm{~mm}$ for 2013-2016, respectively than the long-term average of $612.2 \mathrm{~mm}$. In this paper, we call 2013 and 2014 'dry years' and 2015 and 2016 'very dry years'.

For measurement of soil bulk density (BD) and soil water content volumetrically (SWC) samples of undisturbed soil were collected in $100 \mathrm{~cm}^{3}$ cylinders, and were weighed before and after drying at $105^{\circ} \mathrm{C}$ (Czyż and Dexter, 2008). The BD was calculated as the mass of dry soil per unit volume of moist soil. Soil stability in water was measured in terms of its content of readily dispersible clay (RDC) (g $100 \mathrm{~g}^{-1}$ of soil) using a Hach $2100 \mathrm{AN}$ ratio turbidimeter (Czyż and Dexter, 2008). Ten replicates were used for each year and depth at each field.

SOC was determined by wet oxidation using the Tiurin method (Ostrowska et al., 1991). Soil pH in KCl was measured potentiometrically in a 1:2.5 volumetric ratio suspension in $1 \mathrm{~mol} \mathrm{dm}^{-3} \mathrm{KCl}$ solution (International Organization for Standardization - ISO 10390, 2005). Available $\mathrm{P}$ and $\mathrm{K}$ were determined by the Egner-Rhiem method and available Mg by the Schachtschabel method (Page et al., 1982).

Diatom material was used to measure microbial biodiversity, according to Kawecka (2012) as modified by Stanek-Tarkowska and Noga (2012a,b). Diatoms were chosen for this study because: (1) they are naturally-occurring; (2) different taxa can be identified under a microscope; (3) incidences of the different taxa are countable. Diatoms are a major group of microalgae and are phytoplankton. Because they require light, they occur mainly at or near the soil surface. Diatoms were identified at 1000x magnification using an optical microscope (Nikon ECLIPSE 80i), and keys: Krammer and Lange-Bertalot (1986, 1988, 1991a,b). The number of given species was obtained by counting specimens in a random sample in the ocular fields 
Table 1. Comparison of monthly mean air temperature and total precipitation for the period 2011-2016 with long-term averages (1956-2012) at Krasne Experimental Station (Poland)

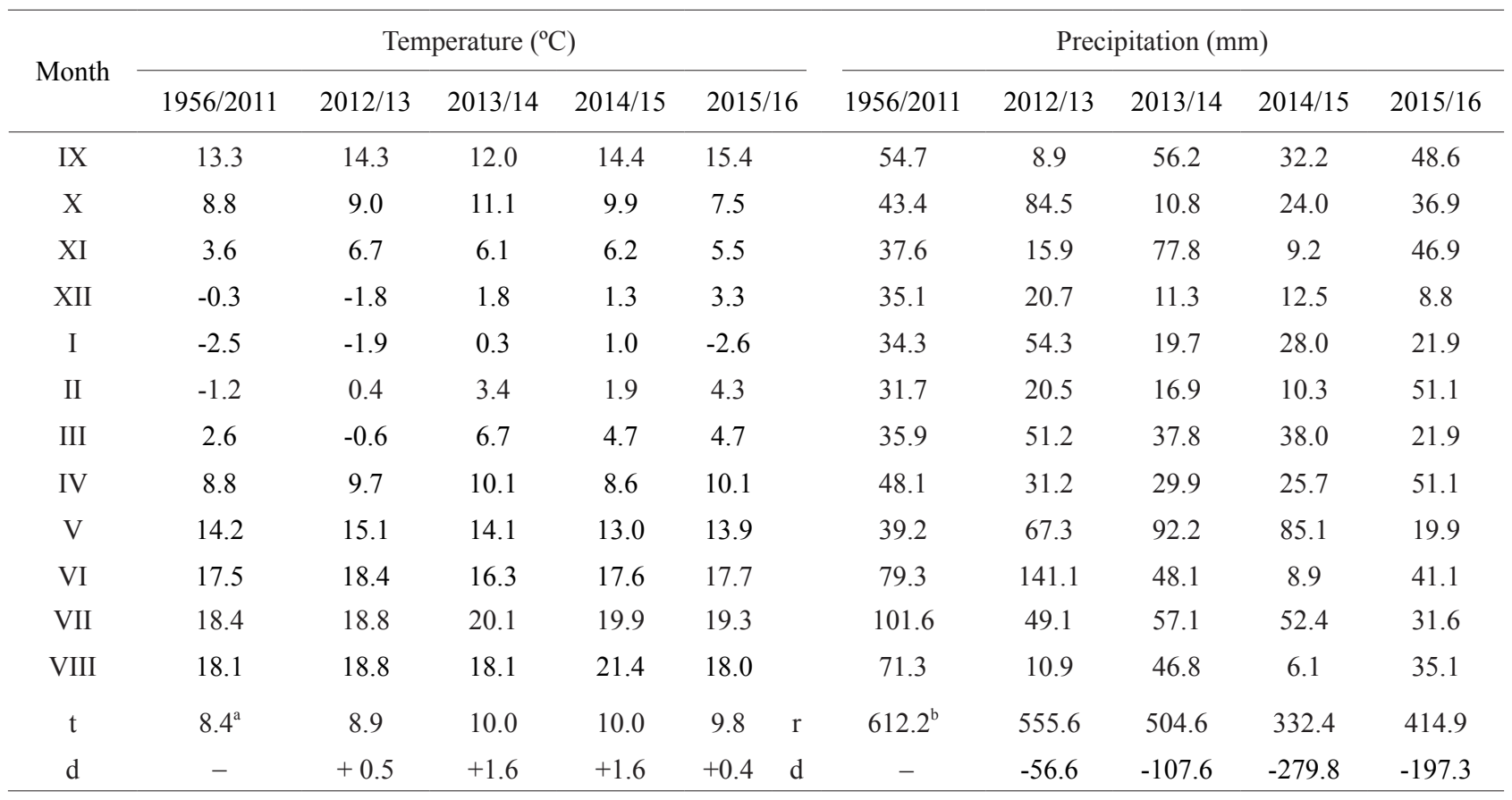

$\mathrm{t}$ - mean air temperature $\left({ }^{\circ} \mathrm{C}\right)$ from sowing to harvest wheat, $\mathrm{r}$ - sum rainfall $(\mathrm{mm})$ from sowing to harvest wheat, $\mathrm{d}-\mathrm{deviations}$ from long-term - annual average temperature $\left({ }^{\circ} \mathrm{C}\right) /$ sum rainfall $(\mathrm{mm}), 8.4^{\mathrm{a}}-$ mean, $612.2^{\mathrm{b}}-$ sum.

Table 2. Soil chemical properties at $0-20 \mathrm{~cm}$ under different tillage for years 2013-2016 $(\mathrm{n}=16)$

\begin{tabular}{ccccc}
\hline & & $\mathrm{P}$ & $\mathrm{K}$ & $\mathrm{Mg}$ \\
\cline { 3 - 5 } Treatment & $\mathrm{pH}_{\mathrm{KCl}}$ & \multicolumn{3}{c}{$\left(\mathrm{mg} \mathrm{kg}^{-1}\right.$ of soil $)$} \\
\hline TT & 5.4 & 101 & 151 & 56 \\
$\mathrm{RT}$ & 5.5 & 128 & 180 & 79 \\
$\mathrm{LSD}_{0.05}$ & $\mathrm{~ns}$ & 12 & 23 & 8 \\
\hline
\end{tabular}

$\mathrm{TT}$ - traditional tillage, $\mathrm{RT}$ - reduced tillage, $\mathrm{LSD}_{0.05}$ - least significant difference, ns - non significant.

of the microscope until 400 incidences had been obtained. The species whose contributions exceeded $5 \%$ of the total were considered as dominants $(<5 \%$ low, $5-20 \%$ medium, $>20 \%$ high domination). The biodiversity or species richness was measured in terms of the number of taxa of diatoms identified. We emphasize that the above method gives us the species richness as a measure of microbial biodiversity and does not give us information about the numbers or densities of diatoms in the two treatments.

Results were evaluated statistically by analysis of variance (ANOVA) which was used to evaluate the effects of the tillage systems on the measured variables. Least significant differences (LSD) were used to compare means $(p<0.05)$. Pearson correlation coefficients were used to show the relations between soil properties, meteorological data and the grain yield of winter wheat (WY) at $p<0.01$ and $\mathrm{p}<0.05$.

\section{RESULTS AND DISCUSSION}

Different tillage practices produce differences in chemical, physical and biological properties of soil and in soil quality (Gajda et al., 2017; Franzluebbers, 2002; Małecka et al., 2015). The soil data from $0-20 \mathrm{~cm}$ depth in Table 2 show after 7 years a greater accumulation of available K, $\mathrm{P}$ and $\mathrm{Mg}$ under RT than TT. Similar results are presented in Małecka et al. (2015) for available $\mathrm{K}$ and $\mathrm{Mg}$ in the 0-5 cm layer. Franzluebbers 2002 reported that higher values of SOC and available $\mathrm{K}, \mathrm{P}$ and $\mathrm{Mg}$ at the soil surface under conservation tillage were directly related to surface residue accumulation.

The data in Table 3 show that accumulations of SOC at the $0-5$ and $5-10 \mathrm{~cm}$ depths were significantly greater by 25 and 7\%, respectively under RT than under TT. Deeper in the soil, SOC was not significantly different between RT and TT and decreased with increasing soil depth in both tillage systems. Similar results have been obtained for the 0-5 cm soil layer: Gajda et al. (2017) reported that SOC content increased by 23\%; Małecka et al. (2015) found an increase of 19.5\%; Franzluebbers (2002) and Mühlbachová et al. (2015) also evaluated zero- or no-tillage (NT) and found that both RT and NT increased SOC in the top layers of soil. 
Tab le 3. Effect of different tillage systems on soil organic carbon, soil water content, soil bulk density and readily dispersible clay (means of 2013-2016, $\mathrm{n}=16$ )

\begin{tabular}{|c|c|c|c|c|c|c|}
\hline \multirow{2}{*}{ Tillage systems } & \multicolumn{6}{|c|}{ Soil layer $(\mathrm{cm})$} \\
\hline & $0-5$ & $5-10$ & $10-15$ & $15-20$ & $20-25$ & $30-35$ \\
\hline \multicolumn{7}{|c|}{ Soil organic carbon, SOC (g $100 \mathrm{~g}^{-1}$ soil) } \\
\hline TT & $0.83^{\mathrm{b}}$ & $0.81^{\mathrm{b}}$ & $0.80^{\mathrm{b}}$ & $0.80^{\mathrm{b}}$ & $0.79^{\mathrm{b}}$ & $0.33^{\mathrm{c}}$ \\
\hline RT & $1.04^{\mathrm{a}}$ & $0.88^{\mathrm{a}}$ & $0.82^{\mathrm{b}}$ & $0.82^{\mathrm{b}}$ & $0.81^{\mathrm{b}}$ & $0.34^{\mathrm{c}}$ \\
\hline \multicolumn{7}{|c|}{ Volumetric soil water content, $\mathrm{SWC}\left(\%, \mathrm{~cm}^{3} \mathrm{~cm}^{-3}\right)$} \\
\hline TT & $32.5^{\mathrm{b}}$ & $31.9^{\mathrm{b}}$ & $30.0^{\mathrm{b}}$ & $29.5^{\mathrm{b}}$ & $30.5^{\mathrm{b}}$ & $29.7^{\mathrm{b}}$ \\
\hline RT & $38.5^{\mathrm{a}}$ & $36.9^{\mathrm{a}}$ & $35.2^{\mathrm{a}}$ & $31.8^{\mathrm{b}}$ & $31.5^{\mathrm{b}}$ & $30.7^{\mathrm{b}}$ \\
\hline \multicolumn{7}{|c|}{ Soil bulk density, $\mathrm{BD}\left(\mathrm{g} \mathrm{cm}^{-3}\right)$} \\
\hline TT & $1.37^{\mathrm{d}}$ & $1.41^{\mathrm{d}}$ & $1.43^{\mathrm{c}}$ & $1.48^{\mathrm{c}}$ & $1.50^{\mathrm{b}}$ & $1.56^{\mathrm{a}}$ \\
\hline RT & $1.48^{\mathrm{c}}$ & $1.46^{\mathrm{c}}$ & $1.45^{\mathrm{c}}$ & $1.47^{\mathrm{c}}$ & $1.51^{\mathrm{b}}$ & $1.53^{\mathrm{a}}$ \\
\hline \multicolumn{7}{|c|}{ Readily dispersible clay, RDC (g $100 \mathrm{~g}^{-1}$ soil) } \\
\hline TT & $2.73^{\mathrm{a}}$ & $2.64^{\mathrm{a}}$ & $2.65^{\mathrm{a}}$ & $2.51^{\mathrm{a}}$ & $2.61^{\mathrm{a}}$ & $2.80^{\mathrm{a}}$ \\
\hline RT & $1.07^{\mathrm{d}}$ & $1.02^{\mathrm{d}}$ & $1.30^{\mathrm{d}}$ & $1.92^{\mathrm{c}}$ & $2.28^{\mathrm{b}}$ & $2.76^{\mathrm{a}}$ \\
\hline
\end{tabular}

TT - traditional tillage, RT - reduced tillage. Means followed by the same letter are not significantly different $(\mathrm{p}<0.05)$.

SWC was significantly greater under RT than TT at 0-5, 5-10 and 10-15 cm depths. Soil under RT had the highest values of SWC at $0-5 \mathrm{~cm}$. In RT, volumetric $\mathrm{SWC}$ in $0-5$, $5-10$, and $10-15 \mathrm{~cm}$ soil layer increased by 18,16 , and $17 \%$, respectively relative to TT (Table 3). Similarly, Sławiński et al. (2012) found that soil under RT had greater values of SWC at all depths in both a Fluvisol and Cambisol, compared with TT. Czyż and Dexter (2009), and Małecka et al. (2015) reported that RT increased SWC and water availability to crops. McVay et al. (2006) found, in the years with higher precipitation, no-difference of SWC under CT, RT or NT, but in dry years SWC was greater in NT.

BD increased under RT at the $0-5$ and $5-10 \mathrm{~cm}$ depths by 0.11 and $0.05 \mathrm{~g} \mathrm{~cm}^{-3}$, respectively compared with TT. In deeper layers no difference was found (Table 3). Several authors: Fabrizzi et al. (2005), McVay et al. (2006), Czyż and Dexter (2009), Małecka et al. (2015), Mühlbachová et al. (2015), and Gajda et al. (2017) found an increase in soil $\mathrm{BD}$ with RT or NT in comparison with TT.

RDC decreased under RT throughout the profile and therefore increased soil stability in water in comparison with TT (Table 3). Values of RDC in the $0-5,5-10$ and $10-15 \mathrm{~cm}$ layers under RT were half as big as in TT. Czyż and Dexter (2009) also found that RT and NT soils showed lower values of RDC and increased stability in water and improved physical quality compared with traditional tillage.
Microbial biodiversity was found to be greater under RT than TT (Table 4). In soil samples from both treatments a total 197 taxa of diatoms were identified. RT was richer in species (139 taxa) than TT (102 taxa) and this difference suggests that some taxa are more sensitive to tillage than others. Two main factors may have contributed to this difference. Firstly, there is the effect of soil mixing during tillage. The surface layer, where the diatoms live, was mixed with $25 \mathrm{~cm}$ of soil in TT but only with $10 \mathrm{~cm}$ of soil in RT. Secondly, the soil surface layer in RT had greater SOC content as shown in Table 3 and as found by StanekTarkowska et al. (2015). Greater SOC content also leads to improved soil physical properties. Table 4 enables the diatom communities under RT and TT to be compared. In the very dry years (2015 and 2016) under RT, dominant species exceeded 20\%, but under TT were less than 20\% (Table 4). Comparable results were obtained by Stanek-Tarkowska and Noga (2012a,b) in RT and TT systems under maize in a field experiment in Dąbrowa (voivodship Podkarpackie, Poland) on a silty soil. They observed greater biodiversity of diatoms (62 taxa) under RT than under TT (38 taxa) in a silty soil. The soil algae, including diatoms, produce amino acids, organic acids, polysaccharides and vitamins. Their biomass is a source of humus and nitrogen compounds.

The grain yield of winter wheat (WY) in the dry years 2013 and 2014 under RT was significantly less by 10 and $8 \%$, respectively than under TT (Table 5 ). However values 
Table 4. Percentage contributions of dominant diatoms under traditional tillage (TT) and reduced tillage (RT)

\begin{tabular}{|c|c|c|c|c|c|c|c|c|}
\hline \multirow{2}{*}{ Taxa } & \multicolumn{2}{|c|}{2013} & \multicolumn{2}{|c|}{2014} & \multicolumn{2}{|c|}{2015} & \multicolumn{2}{|c|}{2016} \\
\hline & TT & RT & TT & RT & TT & RT & TT & RT \\
\hline \multicolumn{9}{|c|}{ Eolimna minima } \\
\hline \multicolumn{9}{|c|}{ Hantzschia amphioxys } \\
\hline \multicolumn{9}{|c|}{ Lemnicola hungarica } \\
\hline \multicolumn{9}{|c|}{ Luticola paramutica } \\
\hline \multicolumn{9}{|c|}{ Mayamaea atomus var atomus } \\
\hline \multicolumn{9}{|c|}{ Mayamaea atomus var permitis } \\
\hline \multicolumn{9}{|c|}{ Nitzschia acidoclinata } \\
\hline \multicolumn{9}{|c|}{ Nitzschia pusilla } \\
\hline \multicolumn{9}{|c|}{ Pinularia obscura } \\
\hline \multicolumn{9}{|c|}{ Stauroneis borrichii } \\
\hline \multicolumn{9}{|c|}{ Stauroneis termicola } \\
\hline \multicolumn{9}{|c|}{ Sellaphora nana } \\
\hline$\%$ occurrence & & & & & & & & \\
\hline
\end{tabular}

Tab le 5. Grain yield $\left(\mathrm{t} \mathrm{ha}^{-1}\right)$ of winter wheat under traditional tillage (TT) and reduced tillage (RT)

\begin{tabular}{|c|c|c|c|c|c|}
\hline \multirow{2}{*}{ Tillage systems } & \multicolumn{4}{|c|}{ Years } & \multirow{2}{*}{$\begin{array}{l}\text { 4-years } \\
\text { average }\end{array}$} \\
\hline & 2013 & 2014 & 2015 & 2016 & \\
\hline $\mathrm{TT}$ & 7.42 & 7.22 & 6.11 & 6.23 & 6.75 \\
\hline RT & 6.68 & 6.63 & 6.55 & 6.28 & 6.54 \\
\hline Mean & 7.05 & 6.93 & 6.33 & 6.26 & 6.64 \\
\hline
\end{tabular}

$\mathrm{LSD}_{0.05}=0.43$ - for tillage systems, 0.82 - for years, 1.16 for interaction (tillage systems x years).

of WY in the very dry years 2015 and 2016 showed no significant differences. Comparison of the results in Tables 1 and 5, shows an interesting relationship between wheat grain yield and the deviation from the long-term average annual rainfall. In 2015, greater wheat grain yield under RT than under TT (Table 5) corresponds with the largest deviation from long-term - annual sum rainfall (279.8 mm, Table 1). In contrast, for the years 2013 and 2014 (smaller wheat grain yields under RT than under TT) correspond with the smallest deviations from the long-term - annual sum rainfall of 56.6 and $107.6 \mathrm{~mm}$, respectively. Arvidsson et al. (2013) reported similar results where crop yields were 3-5\% smaller under non-inversion tillage than under traditional tillage and emphasized the importance of weather conditions during the growing season for WY.

Tillage practices affect both the physical and chemical properties and have consequences for soil biological activity and soil functions. High correlations were obtained between soil parameters (SOC) and SWC, DB, and RDC (Table 6). These correlations demonstrate the high sensitivity of the studied properties to changes in soil management. WY was found to be correlated with some soil properties and weather conditions, especially precipitation (Table 6). The WY showed positive correlations with SOC (0.445 TT, 0.509 RT), SWC (0.671 TT, 0.542 RT) at $\mathrm{p}<0.05$, and PREC (0.957 TT, $0.525 \mathrm{RT})$ at $\mathrm{p}<0.05$ and $\mathrm{p}<0.01$, and negative correlations with RDC (-0.905 TT, -0.829 RT) at $\mathrm{p}<0.01$.

We can conclude that RT results in improved properties of the surface and near-surface soil layers. It can be argued that the surface layer of soil is the most important for two main reasons. Firstly, because almost everything that goes into or comes out from the soil must pass through it; and secondly, because it is the part of the soil that is potentially erodible especially when it has low stability in water. 
Table 6. Correlation coefficients obtained between selected soil properties, precipitation and winter wheat grain yields

\begin{tabular}{cccc}
\hline \multirow{2}{*}{ Related parameter } & \multicolumn{2}{c}{ Tillage system } \\
\cline { 3 - 4 } & SWC & $0.644^{*}$ & RT \\
\hline \multirow{2}{*}{ SOC } & RDC & $-0.578^{*}$ & $0.741^{*}$ \\
& BD & $-0.789^{* *}$ & $-0.782^{* *}$ \\
& & & $-0.686^{*}$ \\
\multirow{2}{*}{ WY } & SOC & $0.445^{*}$ & $0.509 *$ \\
& SWC & $0.671^{*}$ & $0.542 *$ \\
& RDC & $-0.905^{* *}$ & $-0.829 * *$ \\
& PREC & $0.957^{* *}$ & $0.525^{*}$ \\
\hline
\end{tabular}

TT - traditional tillage, RT - reduced tillage, SOC - soil organic carbon, SWC - soil water content, BD - soil bulk density, RDC - readily dispersible clay, PREC - precipitation, WY - winter wheat grain yield (average for 2013-2016), ${ }^{*} \mathrm{p}<0.05,{ }^{*} \mathrm{p}<0.01$.

\section{CONCLUSIONS}

1. Reduced tillage increased the contents of organic carbon in the $0-5$ and $5-10 \mathrm{~cm}$ soil layers in comparison with traditional tillage.

2. Soil under reduced tillage also showed greater soil water content and bulk density, especially in the top layers, than traditional tillage.

3. The amount of readily dispersible clay was found to be reduced in soil under the non-inversion tillage (reduced tillage), throughout the profile and therefore increased soil stability in water in comparison with traditional tillage.

4. The soil under reduced tillage had greater diversity of diatoms (139 taxa) than that under traditional tillage (102 taxa), and this suggests that some taxa are more sensitive to tillage than others.

5 . Yield of winter wheat was positively correlated with soil organic carbon $(0.445$ traditional tillage, 0.509 reduced tillage), soil water content (0.671 traditional tillage, 0.542 reduced tillage), precipitation (0.957 traditional tillage, 0.525 reduced tillage), and negatively correlations with readily dispersible clay $(-0.905$ traditional tillage, -0.829 reduced tillage).

6. Reduced tillage improves the chemical, physical and biological status of the most important part of the soil and we suggest that reduced tillage increases the sustainability of the soil resource.

Conflict of interest: The Authors do not declare any conflict of interest.

\section{REFERENCES}

Arvidsson J., Westlin A., and Sörensson F., 2013. Working depth in non-inversion tillage - effects on soil physical properties and crop yield in Swedish field experiments. Soil Till. Res., 126, 259-266.
Czyż E.A. and Dexter A.R., 2008. Soil physical properties under winter wheat grown with different tillage systems at selected locations. Int. Agrophysics, 22, 191-200.

Czyż E.A. and Dexter A.R., 2009. Soil physical properties as affected by traditional, reduced and no-tillage for winter wheat. Int. Agrophys., 23, 319-326.

Dexter A.R. and Czyż E.A., 2000. Effect of management on the dispersibility of clay in sand soil. Int. Agrophysics, 14, 269-272.

Fabrizzi K.P., García F.O., Costa J.L., and Picone L.I., 2005. Soil water dynamics, physical properties and corn and wheat responses to minimum and no-tillage systems in the southern Pampas of Argentina. Soil Till. Res., 8, 57-69.

Franzluebbers A.J., 2002. Soil organic matter stratification ratio as in indicator of soil quality. Soil Till. Res., 66, 95-100.

Gajda A.M., Czyż E.A., Dexter A.R., Furtak K.M., Grządziel J., and Stanek-Tarkowska J., 2018. Effect of different soil management practices on soil properties and microbial diversity. Int. Agrophys., 32, 81-91.

Gajda A.M., Czyż E.A., Stanek-Tarkowska J., Dexter A.R., Furtak K.M., and Grządziel J., 2017. Effect of long-term tillage practices on the quality of soil under winter wheat. Plant Soil Environ., 63, 236-242.

International Standardization Organization (ISO), 2005. Soil quality - determination of pH. ISO 10390, Geneva.

IUSS Working Group WRB, 2006. World Reference Base for Soil Resources. 2nd edition. World Soil Resources Reports No. 103. FAO, Rome, 132.

Kawecka B., 2012. Diatom diversity in streams of the Tatra National Park (Poland) as indicator of environmental conditions. Szafer Institute of Botany, Polish Academy of Sciences, Kraków, Poland.

Kołodziejczyk M., Antonkiewicz J., and Kulig B., 2017. Effect of living mulches and conventional methods of weed control on weed occurrence and nutrient uptake in potato. International Journal of Plant Production, 11(2), 275-284. http://ijpp.gau.ac.ir//article_3424_e69d66817514b0ab6d2ca0e1c0996e8e.pdf

Kordas L., 2009. Economic effectiveness of various tillage systems in continuous cropping winter wheat (in Polish). Fragmenta Agronomica, 26(1), 42-48.

Krammer K. and Lange-Bertalot H., 1986. Bacillariophyceae. Teil 1. Naviculaceae. In: Süßwasserflora von Mitteleuropa (Eds H. Ettl, J. Gerloff, H. Heyning and D. Mollenhauer), Gustav Fisher Verlag, Stutttgart, New York.

Krammer K. and Lange-Bertalot H., 1988. Bacillariophyceae: Teil 2. Bacillariaceae, Epithemiaceae, Surirellaceae. In: Süßwasserflora von Mitteleuropa (Eds H. Ettl, J. Gerloff, H. Heyning and D. Mollenhauer), Gustav Fisher Verlag, Stutttgart, Germany.

Krammer K. and Lange-Bertalot H., 1991a. Bacillariophyceae. Teil 3. Centrales, Fragilariaceae, Eunotiaceae. In: Süßwasserflora von Mitteleuropa (Eds H. Ettl, J. Gerloff, H. Heyning and D. Mollenhauer), Gustav Fischer Verlag, Stuttgart, Jena, Germany.

Krammer K. and Lange-Bertalot H., 1991b. Bacillariophyceae. Teil 4. Achnanthaceae, Kritische Erganzungen zu Navicula (Lineolate) und Gomphonema esamtliteraturverzeichnis. In: Süßwasserflora von Mitteleuropa. (Eds H. Ettl, J. Gerloff, H. Heyning, D. Mollenhauer), Gustav Fischer Verlag, Stuttgart, Jena, Germany. 
Malecka I., Blecharczyk A., Sawińska Z., Swędrzyńska D., and Piechota T., 2015. Winter wheat yield and soil properties response to long-term non-inversion tillage. J. Agric. Sci. Technol., 17, 1571-1584.

McVay K.A., Budde J.A., Fabrizzi K., Mikha M.M., Rice C.W., Schlegel A. J., and Thompson C., 2006. Management effects on soil physical properties in longterm tillage studies in Kansas. Soil Sci. Soc. Am. J., 70, 434-438.

Mikanová O., Šimon T., Javůrek M., and Vach M., 2012. Relationships between winter wheat yields and soil carbon under various tillage systems. Plant Soil Environ., 58, 540-544.

Mühlbachová G., Kusá H., and Růžek P., 2015. Soil characteristics and crop yields under different tillage techniques. Plant Soil Environ., 61, 566-572.

Ostrowska A., Gawliński S., and Szczubiałka Z., 1991. Methods of analysis and estimation of soil and plant properties (in Polish). Institute of Environmental Protection, Catalog Press, Warsaw, Poland.

Pabin J., Lipiec J., Włodek S., and Biskupski A., 2003. Effect of different tillage systems and straw management on some physical properties of soil on the yield of winter rye in monoculture. Int. Agrophysics, 17, 175-181.

Page A.L., Miller R.H., and Keeney D.R., 1982. Methods of soil analysis. Part 2. Chemical and Microbiological Properties, Madison, Am. Soc. Agron. Soil Sci. Soc. America.
Pisulewska E., Poradowski R., Antonkiewicz J., and Witkowicz R., 2009. The effect of variable mineral fertilization on yield and grain mineral composition of covered and naked oat cultivars. J. Elementology, 14(4), 763-772. DOI: 10.5601/jelem.2009.14.4.763-772, http://jsite.uwm.edu.pl/ articles/view/207/

Polish Society of Soil Science PTG, 2008. Particle size distribution and textural classes of soils and mineral materials - classification of Polish Society of Soil Science - PTG (in Polish). Soil Science Annual, 2009, 60(2), 5-16.

Slawiński C., Cymerman J., Witkowska-Walczak B., and Lamorski K., 2012. Impact of diverse tillage on soil moisture dynamics. Int. Agrophys., 26, 301-309.

Stanek-Tarkowska J. and Noga T., 2012a. The diatoms communities developing on dust soils under sweet corn cultivation in Podkarpackie region. Fragmenta Floristica et Geobotanica Polonica, 19, 525-536.

Stanek-Tarkowska J. and Noga T., 2012b. Diversity of diatoms (Bacillariophyceae) in the soil under traditional tillage and reduced tillage. Inżynieria Ekologiczna, 30, 287-296.

Stanek-Tarkowska J., Noga T., Kochman N., Peszek L., Pajączek A., and Kozak E., 2015. The diversity of diatom assemblages developed on fallow soil in Pogórska Wola near Tarnów (Southern Poland). Acta Agrobotanica, 68, $33-42$. 